\title{
Analysis of genetic diversity among Iranian populations of Ficus carica L. (Moraceae)
}

\author{
Mohammad Reza Zolfaghari, Fahimeh Salimpour*, Fariba Sharifnia, \\ Maryam Peyvandi, Sayeh Jafari Marandi \\ Department of Biology, Tehran North Branch, Islamic Azad University, \\ Vafadar Blv., Shahid Sadoghi St, Hakimiyeh, 1651153311, Tehran, Iran \\ *Corresponding author E-mail: fahimehsalimpour89@gmail.com
}

\begin{abstract}
Ficus carica L. is a species of Moraceae family that has been cultivated in different parts of the world from ancient time. Its fruit is eaten by human and has several medicinal properties. This species widely grows and cultivated in various parts of Iran. For this, in the current study, we investigated infraspecific genetic variation and population structure of $F$. carica in the country. 14 natural populations of $F$. carica were collected and their genomic DNA were extracted and tested with RAPD molecular technique. Parameters of population's genetic diversity varied among the studied populations. In addition, AMOVA test revealed significant variations among the populations. The studied populations clustered separately in UPGMA tree of RAPD data, moreover PCA and MDS plots produced similar results. STRUCTURE analysis revealed the best number of $\mathrm{k}=9$. Based on Nei's genetic distance, we had nine distinct groups. Genetic clustering patterns according to UPGMA trees of RAPD data and Nei's genetic distance were more similar with the results of STRUCTURE analysis. The small amount of $\mathrm{Nm}$ (the product of the effective size of individual populations $(\mathrm{N})$ and the rate of migration among them $(\mathrm{m})$ ) value showed limited gene flow among the studied populations, therefore it seems that high genetic variations among these populations may be related less or few amount of gene exchange among populations.
\end{abstract}

Key words: RAPD; Ficus carica; population; genetic diversity

\section{Introduction}

Investigation of genetic differences within cultivated crop plant is crucial to plant breeding strategies and conservation of genetic resource (Sheidai et al., 2014; Fu, 2015). Esquinas Alcazar (2005) has believed that losses in the genetic variation of crop plant due to commercialization have led to the need to conserve the exits genetic resources as much as possible, not only for the long-term survival of the species but also to ensure enough variability for breeding programs.

Moritz (1994) has suggested that the infraspecific genetic diversity is important for the persistence of plant species in wild habitats. The diagnosis of genetic difference and its distribution are very important points to characterize its conservation status. In addition, allopathic speciation may occur and a taxon is formed by separation of different populations of the same species.

Family Moraceae Gaudich. was composed of about 40 genera with more than 1400 species (Watson, Dallwitz, 2004). The genus Ficus L. with more than 745 species is one of them and Ficus carica L. $(2 n=26)$ is the most important species of the genus (Berg, 1989; Falistocco, Antonielli, 2002). This species naturally distributed in north, northwest, northeast and central parts of Iran. Moreover, the cultivated plants of this species have been found in throughout the country. However, no infraspecific taxon has been recognized for $F$. carica in Iran (Azizian, 2001).

Several studies (Beck, Lord, 1988; Kislev et al., 2006) have revealed that $F$. carica is the oldest fruit crop known as an insect pollinated and gynodioecious species. Two ecotypes are found with similar frequencies in wild populations of this species: common figs are unisexual female trees and caprifigs are bisexual with functional male trees (Valdeyron, Lloyd, 1979). However, F. carica is widespread in the Mediterranean basin countries since it is well adapted to different ecological conditions (Mars, 2003). It has estimated that the annual fruit production of Fig is about 1,065,480 tons (F.A.O., 2011). Different evaluations (Aksoy et al., 2003; Şimşek, Yildirim, 2010; Dalkılıç et al., 2011) have revealed that there has been little research dealing with the genetic diversity in the germplasm of $F$. carica.

In the current study, we investigated infraspecific genetic variations and population structure of fourteen populations of $F$. carica in Iran using Random Amplified Polymorphic DNA (RAPD) molecular technique, in order to find different genotypes of this plant in the country and introduce them for better conservations and breeding programs. As we could search, no similar work is available for this species in Iran. 


\section{Methods}

\section{Plant samples}

In this study, fourteen cultivated populations of $F$. carica were selected from different parts of the country (Table 1, Fig. 1). Individuals of each population were indentified according to descriptions provided in valuable references (Azizian, 2001). Voucher specimens were deposited at Herbarium of Islamic Azad University Tehran( IAUNT).

Table 1. Localities address and voucher number of the studied populations.

\begin{tabular}{|c|c|c|}
\hline Population No. & Localities address & Voucher number \\
\hline 1 & Mazandaran province, Savad kooh,1500 m. & 17429 IAUNT \\
\hline 2 & Fars province, Estahban, 1600 m. & 17430 IAUNT \\
\hline 3 & Markazi province, Mahallat, $1550 \mathrm{~m}$. & 17431 IAUNT \\
\hline 4 & Chaharmahal and Bakhtiari, Shar-e- Kord, 1700 m. & 17432 IAUNT \\
\hline 5 & Ilam province, ilam, 1400 m. & 17433 IAUNT \\
\hline 6 & Kurdistan province, Sanandaj, 1550 m. & 17434 IAUNT \\
\hline 7 & Yazd province, Yazd, 1430 m. & 17435 IAUNT \\
\hline 8 & Kerman province, Kerman, 1430 m. & 17436 IAUNT \\
\hline 9 & Zanjan province, Tarom, 1720 m. & 17437 IAUNT \\
\hline 10 & West Azerbaijan province, Khoy, 1720 m. & 17438 IAUNT \\
\hline 11 & East Azerbaijan province, Aras, 1690 m. & 17439 IAUNT \\
\hline 12 & Sistan and Baluchistan province, Chabahar, 1100 m. & 17440 IAUNT \\
\hline 13 & Khorasan Razavi, Mashhad, 1320 m. & 17441 IAUNT \\
\hline 14 & Semnan province, Semnan, 1450 m. & 17442 IAUNT \\
\hline
\end{tabular}

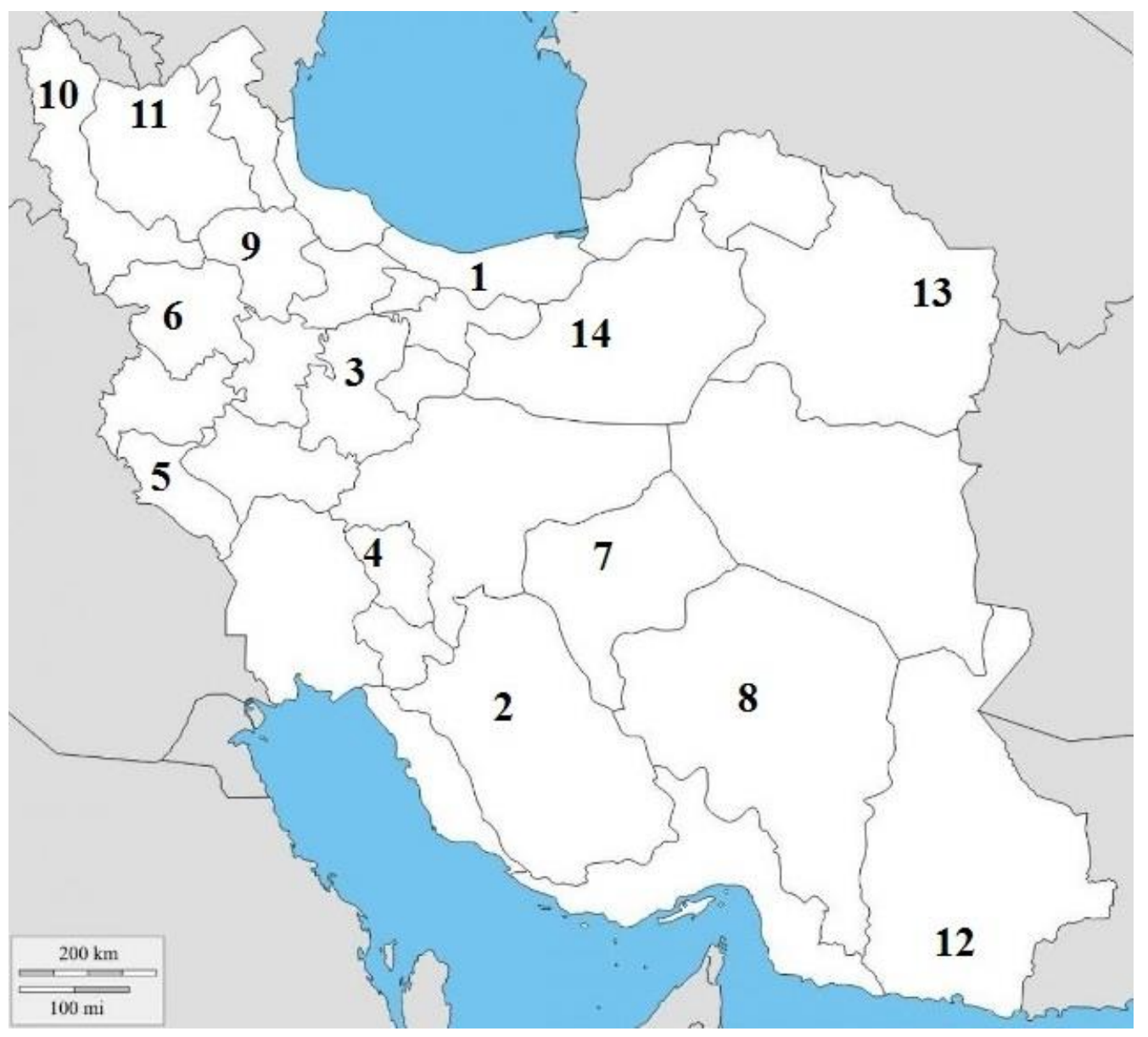

Fig.1. Distribution map of the studied populations of F. carica in Iran.

\section{RAPD primers and PCR reactions}

We used six RAPD primers, OPH02 (TCGGACGTGA), OPH12 (ACGCGCATGT), OPA01 (CAGGCCCTTC), OPA05 (AGGGGTCTTG), OPA11 (CAATCGCCGT) and OPA16 (AGCCAGCGAA), for the amplification of random genomic DNA banding patterns. The $\mathrm{PCR}$ reactions were carried out in a $25 \mu$ volume mixture containing: genomic DNA $3 \mu \mathrm{l}, 0.25 \mathrm{mM} \mathrm{dNTPs,0.25} \mathrm{mM} \mathrm{MgCl} 2,9$ $\mu \mathrm{l}$ primer, $0.5 \mathrm{U}$ of Taq DNA Polymerase and $1 \mu \mathrm{l}$ enzyme buffer. These reactions were performed in Gene Amp PCR System 
9700 Thermal Cycler. The amplification program was as follows: an initial denaturing step at $94^{\circ} \mathrm{C}$ for 5 min, followed by 35 cycles of $94^{\circ} \mathrm{C}$ for $1 \mathrm{~min}, 34.2^{\circ} \mathrm{C}$ for $45 \mathrm{~S}$, and $72^{\circ} \mathrm{C}$ for $2 \mathrm{~min}$, and a final extension at $72^{\circ} \mathrm{C}$ for $5 \mathrm{~min}$.

\section{Statistical analyses}

We coded obtained RAPD bands as binary traits (presence $=1$, absence $=0$ ) and applied them for later genetic variation analyses. We determined several important factors such as effective allele's numbers, Shannon information index (I), Nei's gene diversity $(\mathrm{H})$, and percentage of polymorphism (Freeland et al., 2011). We used Nei's genetic distance among the studied populations of $F$. carica for UPGMA tree clustering (Huson, Bryant, 2006; Freeland et al., 2011). Cluster analysis was carried out based on quantitative and qualitative characteristics using Unweighted Paired Group Method with Arithmetic Mean (UPGMA), Principal Coordinate Analysis (PCA) and Multidimensional Scaling (MDS) methods.

GenAlex 6.4 and Geno-Dive ver.2 softwares were used for analysis of molecular variance (AMOVA) test with 1000 permutations and Nei's Gst analysis, respectively (Meirmans, Tienderen, 2004; Peakall, Smouse, 2006 ). Moreover, we estimated population's genetic variations studied by $G_{\text {st }}$ and $D_{\text {est }}$ (Hedrick, 2005). According to Bayesian based model STRUCTURE analysis, we studied the population genetic structure (Pritchard et al., 2000).

The Evanno analysis was performed on STRUCTURE outputs to estimate the best number of $\mathrm{K}$ by using delta $\mathrm{K}$ value (Evanno et al., 2005). Simulations were carried out 10 times for each $K=$ ? value with 10,000 burnings and 50,000 MCMC iterations.

\section{Results}

Parameters of the population's genetic variations determined in 14 geographical populations of $F$. carica were listed in Table 2. The highest $(59.55 \%, 0.19$ and 0.29$)$ and lowest $(10.11 \%, 0.026$ and 0.04$)$ values of polymorphism percentage $(P \%)$, gene diversity ( $\mathrm{He}$ ) and Shanon information index (I) were found in population no. 5 and 1, respectively.

Table. 2. Parameters of genetic diversity among the studied populations of $F$. carica. Abbreviations: Na $=$ Number of Different Alleles, $\mathrm{Ne}=$ Number of Effective Alleles $=1 /\left(p^{\wedge} 2+q^{\wedge} 2\right), I=$ Shannon's Information Index $=-1 *(p$ * $\operatorname{Ln}(p)+q$ * $\operatorname{Ln}(q)), \mathrm{He}=$ Expected Heterozygosity $=2 * \mathrm{p} * \mathrm{q}$, UHe = Unbiased Expected Heterozygosity $=(2 \mathrm{~N} /(2 \mathrm{~N}-1))$, He Where for Diploid Binary data and assuming Hardy-Weinberg Equilibrium, $q=(1-\text { Band Freq. })^{\wedge} 0.5$ and $p=1-q$ (populations number are according to Table 1).

\begin{tabular}{ccccccc}
\hline Populations no. & $\mathrm{Na}$ & $\mathrm{Ne}$ & $\mathrm{I}$ & $\mathrm{He}$ & $\mathrm{UHe}$ & $\% \mathrm{P}$ \\
1 & 0.427 & 1.037 & 0.043 & 0.026 & 0.029 & $10.11 \%$ \\
2 & 1.135 & 1.289 & 0.267 & 0.175 & 0.184 & $55.06 \%$ \\
3 & 0.596 & 1.167 & 0.144 & 0.097 & 0.108 & $25.84 \%$ \\
4 & 0.809 & 1.202 & 0.182 & 0.120 & 0.130 & $35.96 \%$ \\
5 & 1.225 & 1.316 & 0.294 & 0.193 & 0.204 & $59.55 \%$ \\
6 & 0.506 & 1.133 & 0.112 & 0.076 & 0.081 & $19.10 \%$ \\
7 & 0.708 & 1.165 & 0.143 & 0.095 & 0.103 & $28.09 \%$ \\
8 & 0.933 & 1.226 & 0.199 & 0.132 & 0.144 & $39.33 \%$ \\
9 & 0.629 & 1.097 & 0.095 & 0.060 & 0.065 & $21.35 \%$ \\
10 & 1.067 & 1.264 & 0.248 & 0.162 & 0.173 & $50.56 \%$ \\
11 & 0.787 & 1.161 & 0.151 & 0.098 & 0.105 & $32.58 \%$ \\
12 & 0.921 & 1.232 & 0.204 & 0.135 & 0.145 & $41.57 \%$ \\
13 & 1.067 & 1.242 & 0.229 & 0.148 & 0.158 & $50.56 \%$ \\
14 & 0.888 & 1.180 & 0.174 & 0.112 & 0.124 & $37.08 \%$ \\
\hline
\end{tabular}

Analysis of molecular variance (AMOVA) test (PhiPT $=0.48, \mathrm{P}=0.01$ ) revealed the significant variation among the studied $F$. carica populations. It also showed that, $66 \%$ of total genetic differentiation was due to among population's genetic variation, and the rest (34\%) was due to within population's diversity (Fig. 2).

The studied populations clustered separately in UPGMA tree of molecular RAPD data (Fig. 3), in addition, PCA and MDS plots produced similar outpost (Figs. 4 and 5), Therefore, we discussed UPGMA tree here. This tree had divided into two branches, population no. 2, was registered in a small branch, while the large branch contained the rest populations, which divided into two sub-branches. The small sub-branch had two groups: populations no. 7 and 8 were clustered as a group and population no. 6 was found in another group. The large sub-branch had two groups. In one group, we found five populations, which were observed in two sub-groups. Population no. 11 was clustered separately as sub-group, while in another sub-group, populations no. 11 and 12 were observed as a pair, either populations no. 13 and 14. In another group, the rest populations were clustered as two sub-groups. In one of them, we observed population no.3, but in another subgroup, populations no. 5 and 9 were registered as a pair and populations no. 4 and 1, joined them, gradually. Therefore, we had nine distinct groups among the studied populations. 


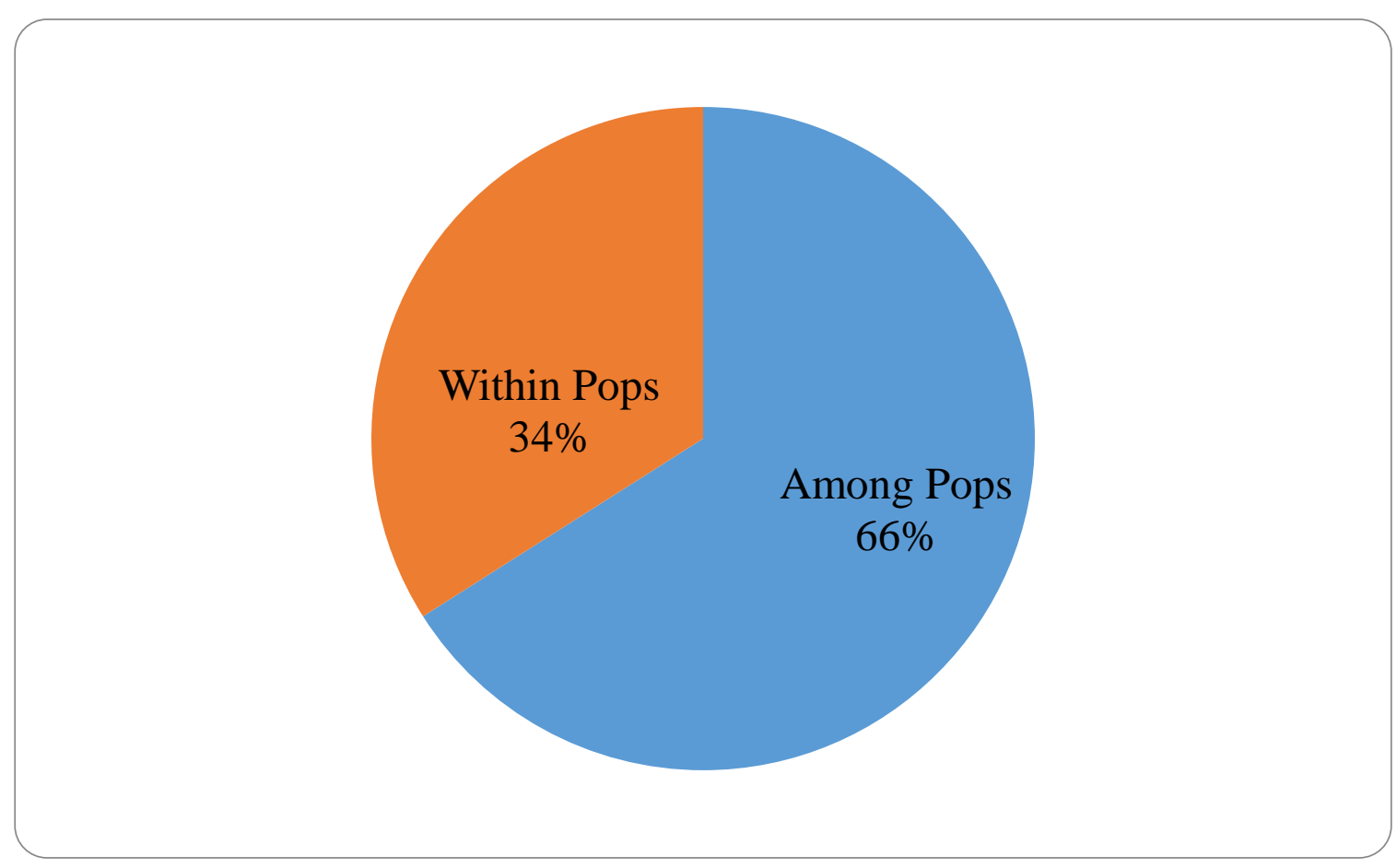

Fig. 2. Results of analysis of molecular variation test among the studied populations.

The Evanno test was done on STRUCTURE analysis showed the best number of $K=9$ (Fig. 6). Meanwhile, results of UPGMA tree according to Nei's Genetic distance revealed the existence of nine groups, with a tiny difference with STRUCTURE analysis results (Fig. 7).

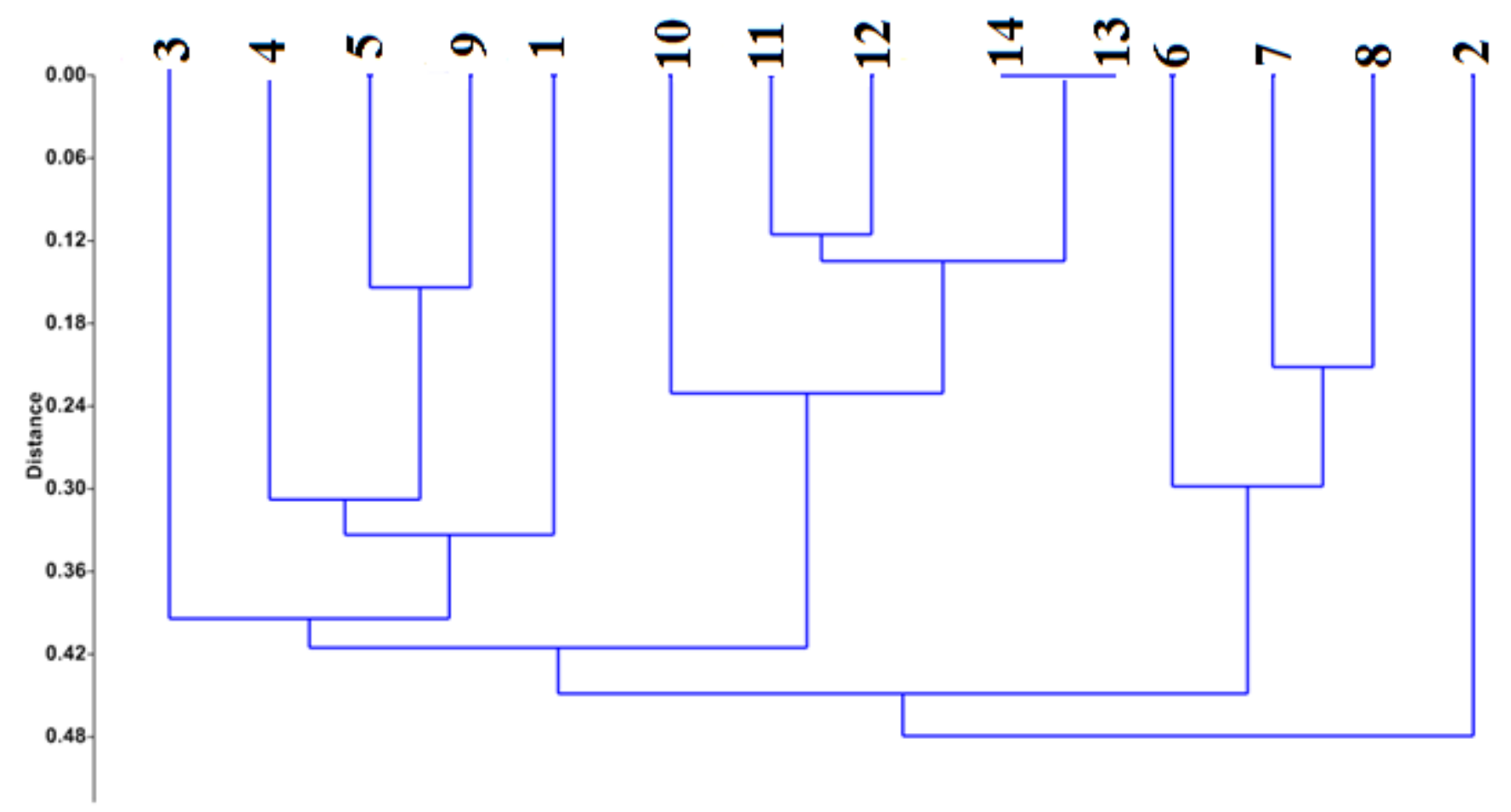

Fig. 3. UPGMA tree of the studied populations based on RAPD data (population's numbers are according to Table 1). 


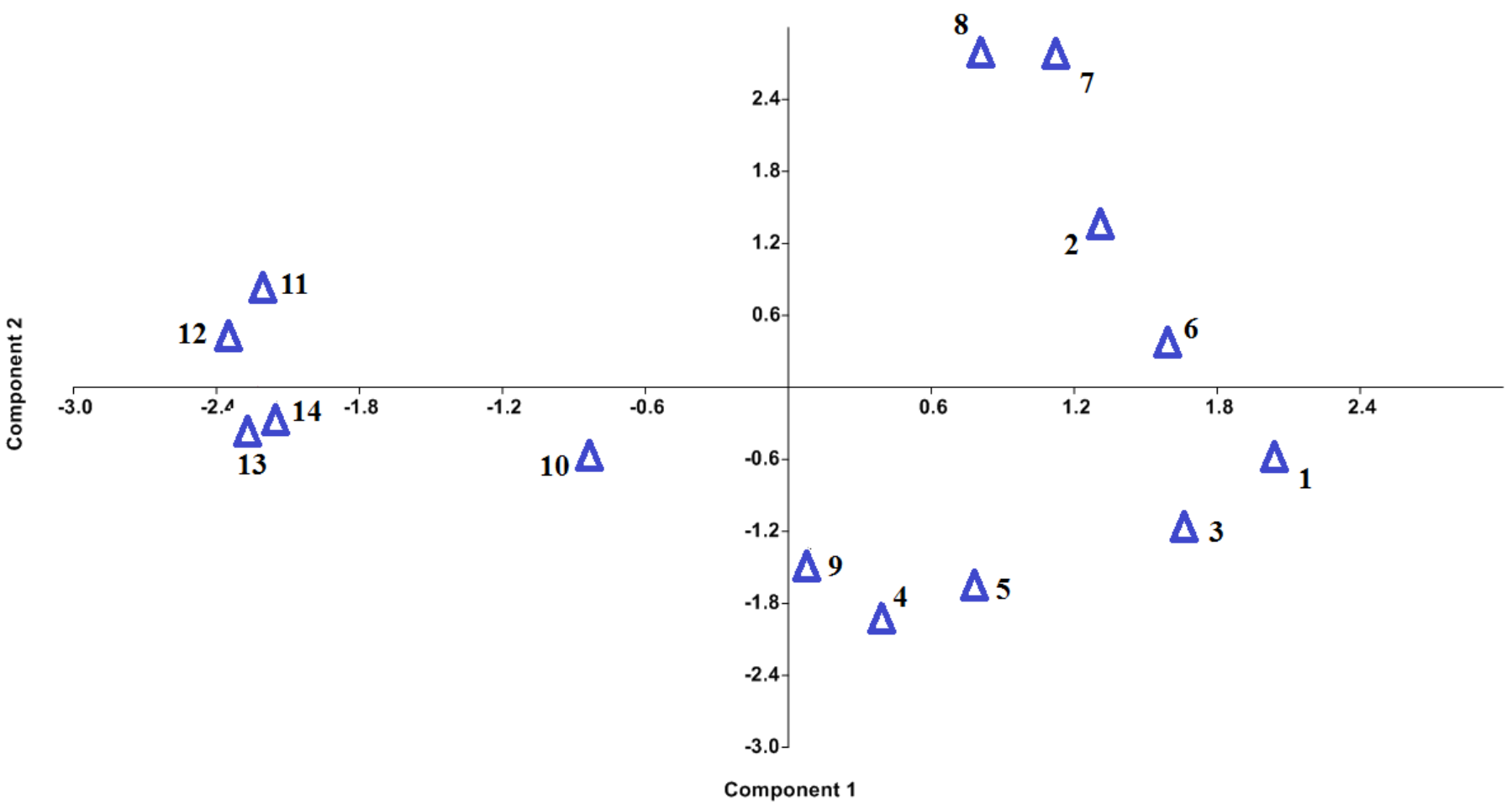

Fig. 4. PCA plot of the studied populations based on the molecular data (population's numbers are according to Table 1).

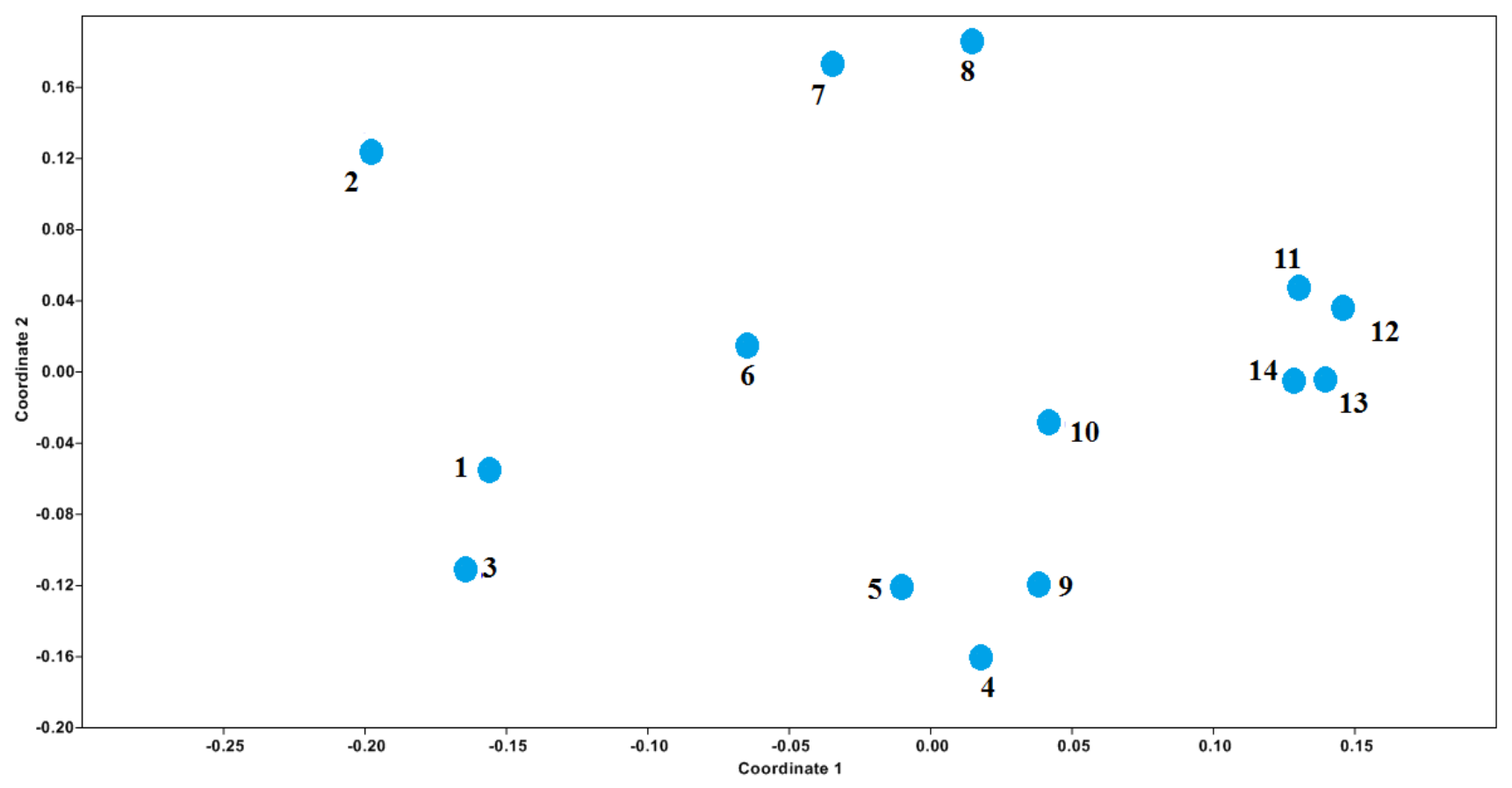

Fig. 5. MDS plot of RAPD data among the studied populations of $F$. carica (population's numbers are according to Table 1) 


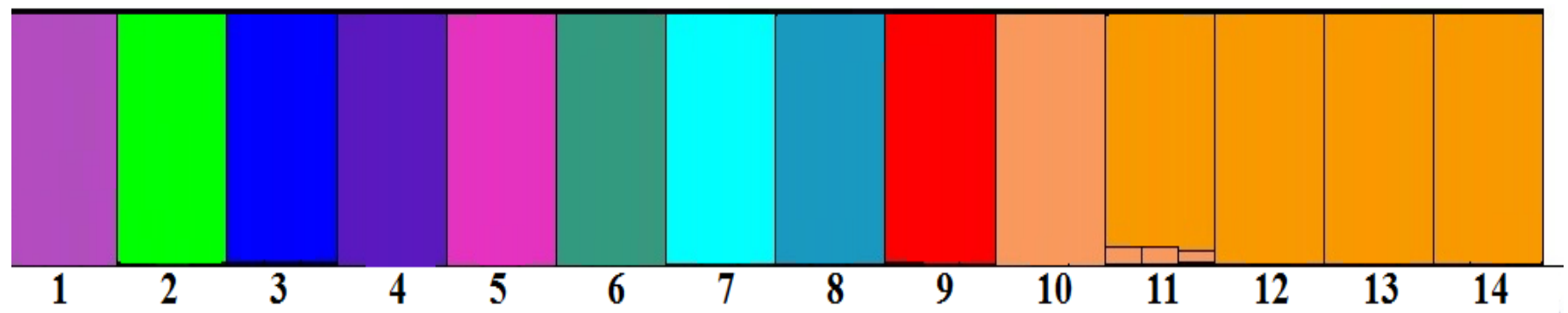

Fig. 6. STRUCTURE analysis of the studied F. carica populations revealed the best number of $\mathrm{k}=10$

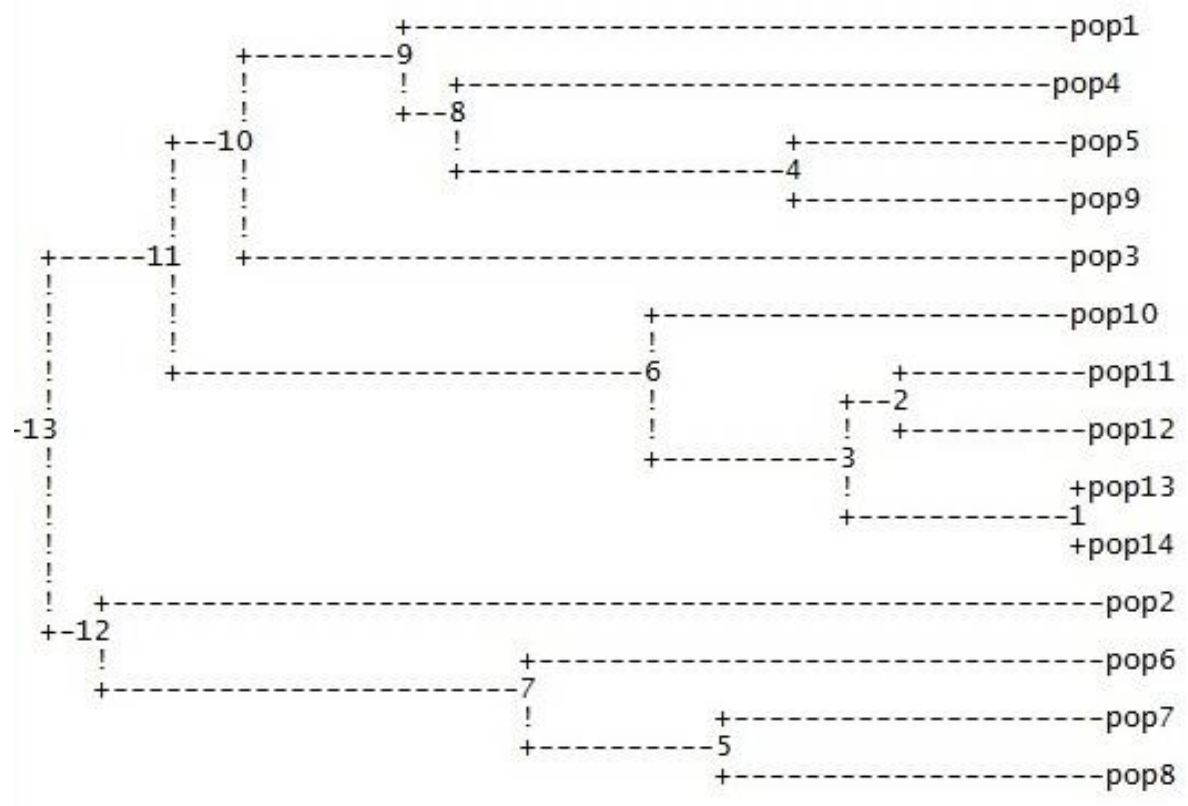

Fig. 7. UPGMA Dendrogram Based Nei's Genetic distance (population's numbers are according to Table 1).

We estimated of gene flow $(\mathrm{Nm})$ among the studied populations from $\mathrm{G}_{\text {st. }}$ Its low amounts $(0.32)$, showed limited amounts of gene flow among the populations.

\section{Discussion}

In the current research, we used RAPD molecular data for evaluating genetic variability and population's structure in Iranian F. carica populations. Because previous studies (Achtak et al., 2009; Kocsis et al., 2005) have proved that compared with other molecular techniques, the Random Amplified Polymorphic DNA (RAPD) method is a simple, fast, efficient, and inexpensive method. In addition, this technique does not need prior knowledge of the sequences of the markers and can create abundant polymorphic bands. For these reasons, RAPD has become a powerful and accurate technique for studying the genetic variations of various plant species (Basheer-Salimia et al., 2012; Sadder, Atteyyeh, 2006; Salhi-Hannachi et al., 2006).

The AMOVA test revealed that most of significant genetic differences belong to among population's variations. These findings were against with previous studies on F. carica. For example, Salhi-Hannachi et al. $(2005,2006)$ studied infraspecific genetic variations of two Tunisian fig collections using ISSR and RAPD methods. They reported that more than $92 \%$ of the total genetic diversity belonged to within populations, while only $8 \%$ of these differences belonged to between populations. More recently, Baziar et al. (2018) evaluated genetic variations of 21 populations of F. carica from Iran (Fars province) and they reported the partitioning of genetic difference among fig population and illustrate the greater variation for within populations.

It seems that difference among these studies was related to sampling distances. In both studies, Salhi-Hannachi et al. (2005) and Baziar et al. (2018), plant samples were collected from two localities or one province, while we collected fourteen populations from different parts of Iran. The distance between our studied populations were very long and in some cases exceed than $2500 \mathrm{~km}$. Our studied populations faced with various ecological conditions and achieved different genetic adaptations for living under different ecological conditions. Therefore, most of genetic variations were found among populations rather than within populations. 
Parameters of genetic diversity such as values of polymorphism percentage ( $P$ \%), gene diversity (He), number of effective alleles (Ne), and Shanon information index (I) varied among the studied populations. According to (Hedrick 2011), genetic diversity among populations, reflected in the variations in allele and genotype frequencies, is frequently measured using Fst and analogs, genetic distance such as Nei's Distance and sequence divergence.

Furthermore, the high difference among these populations could be explained by occurrence of low gene flow among the studied populations. The calculated amount of $\mathrm{Nm}$ was very low; therefore, we had limited gene flow among these populations.

According to UPGMA tree of RAPD data, we found nine distinct genotypes among the studied populations, results of Nei's Genetic distance and STRUCTURE analysis confirmed the existence of these genotypes. However, we had some variations in members of some groups among these methods. In all analyses, populations no. 11, 12, 13 and 14, and also populations no. 7 and 8 were closely together. Furthermore, populations no. 1, 2, 3, 6 and 10 were registered as monotypic groups. Against, we had some differences in some groups. For example, in UPGMA trees of all RAPD data and Nei's genetic distance populations no. 5, 9 clustered closely as a group and populations no. 4 was observed as a distinct group. While in structure analysis, population no. 9 was as a group and populations 4 and 5 were closely grouped.

Some genotypes were made up one population, while the rest were composed of two to four populations. For example, one genotype was composed of populations no. 11, 12, 13 and 14. In the genotype populations with high geographical distance were close together, it seems that these populations had the same origin, or were selected from neighboring populations. Because, genetic structures of them were very similar and gene exchange occurred among them.

\section{Conclusion}

In the present study, we used RAPD molecular technique for investigation of infraspecific genetic variations among 14 natural populations of F. carica. According to AMOVA analysis, most of the significant genetic variations belong to among population's difference. The studied populations divided into nine groups in UPGMA trees of RAPD data and Nei's genetic distance. Meanwhile, more similar results were observed in the STRUCTURE analysis that revealed the best number of $\mathrm{K}=$ 9. The small amount of gene flow among the populations leads to high genetic difference among populations.

\section{References}

Aksoy, U., Can, H.Z., Misirli, A., Kara, S., Seferoglu, G., Sahin, N. (2003). Fig (Ficus carica L.) selection study for fresh market in Western Turkey. Acta Horticulturae, 605, 197-203. https://doi.org/10.17660/ActaHortic.2003.605.29

Achtak, H., Oukabli, A., Ater, M., Santoni, S., Kjellberg, F., Khadari, B. (2009). Microsatellite Markers as Reliable Tools for Fig Cultivar Identification. Journal of American Society for Horticultural Science, 134, 624-631.

https://doi.org/10.21273/JASHS.134.6.624

Basheer-salimia, R., Awad, M., Salama, A., Alseek, S., Harb, J., Hamden, Y. (2012). Molecular Polymorphisms in Palestinian Figs (Ficus carica L.) as Revealed by Random Amplified Polymorphic DNA (RAPD). Journal of Genetic Engineering and Biotechnology, 10, 169-175. https://doi.org/10.1016/j.jgeb.2012.07.001

Baziar, Gh., Jafari, M., Sharifi-Noori, M. S., Samarfard, S. (2018). Evaluation of Genetic Diversity among Persian Fig Cultivars by Morphological Traits and RAPD Markers. Hortscience, 53(5), 613-619. https://doi.org/10.21273/HORTSCI11306-16

Beck, N. G., Lord, E. M. (1988). Breeding system in Ficus carica, the common fig. I. Floral diversity. American Journal of Botany, 75, 1904-1912. https://doi.org/10.1002/j.1537-2197.1988.tb11271.x

Berg, C. C. (1989). Classification and distribution of Ficus. Experientia, 45, 605-611. https://doi.org/10.1007/BF01975677

Dalkılıç, Z., Mesav, H.O., Günver-Dalkılıç, G., Kocataş, H. (2011). Genetic diversity of male fig (Ficus carica caprificusL.) genotypes with random amplified polymorphic DNA (RAPD) markers. African Journal of Biotechnology, 10, 519-526. Esquinas Alcazar, J. (2005). Protecting crop genetic diversity for food security: political, ethical and technical challenges. Nature Reviews Genetics, 6, 946-953. https://doi.org/10.1038/nrg1729

Evanno, G., Regnaut, S., Goudet, J. (2005). Detecting the number of clusters of individuals using the software STRUCTURE: a simulation study. Molecular Ecology, 14(8), 2611-2620. https://doi.org/10.1111/j.1365-294X.2005.02553.x

F.A.O. (2011). Stat Agricultural Data. Available from: http://faostat.ao.org/.

Falistocco, E., Antonielli, L. (2002). Molecular cytogenetics of Vitis vignifera L. and Ficus carica L.: Iocation of rDNA sequences. Proc. XLVI Ital. Soc. Agric. Genet. SIGA Ann. Congr. Giardini, Nexos, Italy.

Falush, D., Stephens, M., Pritchard, J.K., (2007). Inference of population structure using multilocus genotype data: dominant markers and null alleles. Molecular Ecology Notes, 7(4), 574-578. https://doi.org/10.1111/j.1471-

$\underline{8286.2007 .01758 . x}$

Freeland, J.R., Kirk, H., Peterson, S.D. (2011). Molecular Ecology, 2nd ed., UK: Wiley-Blackwell.

https://doi.org/10.1002/9780470979365

Fu, Y.B. 2015. Understanding crop genetic diversity undermodern plant breeding. Theoretical and Applied Genetics, 128 , 2131-2142. https://doi.org/10.1007/s00122-015-2585-y

Hamrick, J. L., Godt, M. J. W. (1996). Conservation genetics of endemic plant species (pp. 281-304). In: Avise, J. C., Hamrick, J. L. (Eds), Conservation genetics. Chapman and Hall. https://doi.org/10.1007/978-1-4757-2504-9 9

Hedrick, P.W. (2005). A standardized genetic differentiation measure. Evolution, 59(8), 1633-1638.

https://doi.org/10.1111/j.0014-3820.2005.tb01814.x 
Huson, D.H., Bryant, D. (2006). Application of phylogenetic networks in evolutionary studies. Molecular Biology and Evolution, 23(2), 254-267. https://doi.org/10.1093/molbev/msj030

Kislev, E. M., Hartman, A., Bar-Yosef, O. (2006). Early domesticated fig in the Jordan Valley. Science, 312, $1372-1374$. https://doi.org/10.1126/science.1125910

Kocsis, M., Jaromi, L., Putnoky, P., Kozma, P. and Borhidi, A. (2005). Genetic Diversity among Twelve Grape Cultivars Indigenous to the Carpathian Basin Revealed by RAPD Markers. Vitis, 44, 87-91.

Mars, M. (2003). Conservation of fig (Ficus carica L.) and pomegrenate (Prunica granatum L.) varieties in Tunisia (pp. 433442). In: Lemons, J., Victor, R., Schaffer, D. (Eds.), Conserving biodiversity in arid regions, Kluwer.

https://doi.org/10.1007/978-1-4615-0375-0 33

Meirmans, P.G. (2012). AMOVA-based clustering of population genetic data, Journal of Heredity, 103(5), 744-750. https://doi.org/10.1093/jhered/ess047

Meirmans, P.G., Van Tienderen, P.H. (2004). GENOTYPE and GENODIVE: two programs for the analysis of genetic diversity of asexual organisms. Molecular Ecology Notes, 4, 792-794. https://doi.org/10.1111/j.1471-8286.2004.00770.x

Moritz, C. (1994). Defining Evolutionary Significant Units for Conservation. Trends in Ecology and Evolution, 9, $373-375$. https://doi.org/10.1016/0169-5347(94)90057-4

Peakall, R., Smouse, P.E. (2006). GENALEX 6: genetic analysis in Excel. Population genetic software for teaching and research. Molecular Ecology Notes, 6, 288-295. https://doi.org/10.1111/j.1471-8286.2005.01155.x

Pritchard, J.K., Stephens, M., Donnelly, P. (2000). Inference of population structure using multilocus genotype data. Genetics, 155(2), 945-959.

Sadder, M.T., Atteyyeh, A.F. (2006). Molecular Assessment of Polymorphism among Local Jordanian Genotypes of The Common Fig (Ficus carica L.). Scientia Horticulturae, 107, 347-351. https://doi.org/10.1016/j.scienta.2005.11.006

Salhi-Hannachi, A., Chatti, K., Saddoud, O., Mars, M., Rhouma, A., Marrakchi, M., Trifi, M. (2006). Genetic Diversity of Different Tunisian Fig (Ficus carica L.) Collection Revealed by RAPD Fingerprints. Hereditas, 143, 15-22.

https://doi.org/10.1111/j.2005.0018-0661.01904.x

Salhi-Hannachi, A., Chatti, K., Mars, M. et al. (2005). Comparative analysis of genetic diversity in two Tunisian collections of fig cultivars based on random amplified polymorphic DNA and inter simple sequence repeats fingerprints. Genetic Resources and Crop Evolution, 52, 563-573. https://doi.org/10.1007/s10722-003-6096-3

Şimşek, M., Yildirim, H. (2010). Fruit characteristics of the selected fig genotypes. African Journal of Biotechnology, 9, 60566060.

Sheidai, M., Ziaee, S., Farahani, F., Talebi, S.M., Noormohammadi, Z. \& Hasheminejad Ahangarani Farahani, Y. (2014). Infraspecific genetic and morphological diversity in Linum album (Linaceae). Biologia, 69, 32-39.

https://doi.org/10.2478/s11756-013-0281-4

Valdeyron, G., Lloyd, D. G. (1979). Sex differences and flowering phenoloy in the common fig (Ficus carica L.). Evolution, 33, 673-685. https://doi.org/10.1111/j.1558-5646.1979.tb04720.x

Watson, L., Dallwitz, M.J. (2004). The families of flowering plants: descriptions, illustrations, identification and information retrieval. Available from: http://delta-intkey.com/ (Accessed 20.05. 2010).

\section{Citation:}

Zolfaghari, M.R., Salimpour, F., Sharifnia, F., Peyvandi, M., Marandi, S.J. (2019). Analysis of genetic diversity among Iranian populations of Ficus carica L. (Moraceae). Acta Biologica Sibirica, 5 (3), 131-138.

Submitted: 10.06.2019. Accepted: 29.08.2019

cross ref http://dx.doi.org/10.14258/abs.v5.i3.6534

(C) 2019 by the authors. Submitted for possible open access publication under the terms and conditions of the Creative Commons Attribution (CC BY) license (http://creativecommons.org/licenses/by/4.0/). 